\title{
ANALISIS KEBUTUHAN FISKAL DAN KAPASITAS FISKAL KABUPATEN LAMONGAN TAHUN 2009-2013
}

\author{
*)Laily Chodariyanti
}

Fakultas Ekonomi

Universitas Islam Lamongan

\begin{abstract}
ABSTRAK
Penelitian ini Untuk Digunakan Kebutuhan Fiskal Dan Kapasitas Fiskal di Kabupaten Lamongan. Metodologi yang digunakan adalah berdasarkan data sekunder dari berbagai sumber resmi sedangkan sampel yang digunakan adalah untuk periode 2009-2013 . alat analisis data yang digunakan dalam penelitian ini adalah metode $\backslash$ kebutuhan fiskal dan kapasitas fiskal di Kabupaten Lamongan . Hasil analisis jawaban yang diperoleh bahwa kebutuhan fiskal sangat hight dan fluktuaktif tentang perkembangan Anggaran antara kapasitas fiskal sangat baik .
\end{abstract}

Kata kunci : kebutuhan fiskal, kapasitas fiskal, Kabupaten Lamongan

\section{PENDAHULUAN}

Pembangunan

berorientasi pada peningkatan pembangunan daerah. Hal ini ditegaskan dalam GBHN (1993: 2002) bahwa pembangunan daerah senantiasa ditingkatkan dan dilaksanakan secara terpadu, selaras, serasi dan seimbang serta diarahkan supaya pembangunan yang berlangsung di daerah sesuai dengan prioritas dan potensi daerah agar laju pertumbuhan antar daerah semakin serasi dan seimbang, sehingga pelaksanaan pembangunan nasional dan hasil-hasilnya semakin merata di seluruh Indonesia. Pelaksanaan otonomi daerah di Indonesia telah berlaku efektif pada tahun 2001. Daerah harus dapat mengembangkan potensi ekonomi daerah agar kesejahteraan meningkat.dan masyarakat mendorong kemandirian daerah agar mampu bersaing di era globalisasi.

Penyerahan kewenangan pemerintahan pusat kepada daerah disertai dengan kewenangan pengelolaan keuangan. Pemerintah daerah harus memiliki sumbersumber penerimaan sendiri untuk membiayai pengeluaran (Simanjuntak dalam Prosoding, 1999:20). Penerimaan daerah menurut Peraturan Menteri Dalam Negeri Nomor 13 Tahun 2006 tentang Pedoman Pengelolaan Keuangan Daerah adalah uang yang masuk ke kas daerah, sedangkan pendapatan daerah merupakan hak pemerintah daerah yang diakui sebagai penambah nilai kekayaan bersih. Penerimaan daerah ditunjukan dengan besaran Pendapatan Asli Daerah (PAD) yang dimiliki masing-masing daerah. 
Pendapatan asli daerah merupakan salah satu kriteria penting untuk mengetahui dan mengukur secara nyata kemampuan daerah dalam pelaksanaan otonomi daerah.

$$
\text { Dalam kenyataannya, }
$$

pelaksanaan otonomi daerah masih tidak sesuai dengan konsep. Hal ini dapat terlihat dari lemahnya pengembangan kebijakan kelembagaan ditinjau dari minimnya prakarsa daerah terhadap program otoda. Dalam bidang keuangan untuk pelaksanaan jasa publik yang seharusnya dibiayai pemerintah daerah dengan $\mathrm{PAD}$, ternyata masih mengandalkan subsidi dari pemerintah pusat dalam bentuk Dana Alokasi Umum (DAU). Salah satu Pemeritah Daerah yang mengandalkan PAD untuk pembangunan daerahnya adalah Kabupaten Lamongan dengan kontribusi pendapatan $48,59 \%$ terhadap PAD.

$$
\text { Kabupaten Lamongan }
$$

merupakan daerah yang memiliki potensi relatif tinggi untuk meningkatkan kemandirian daerah. Sektor pertanian memberikan kontribusi terbesar terhadap PDRB kabupaten Lamongan. Peran PAD sangat besar terhadap jumlah pendapatan keselurhan daerah belumlah cukup untuk menjadi kabupaten Lamongan yang mandiri. Hal ini dapat dilihat dari besarnya dana alokasi umum yang masih sangat tinggi. Kabupaten Lamongan dengan berbagai potensi ekonomi yang ada diharapkan menjadi daerah yang mandiri ditinjau dari segi keuangan sehingga pembangunan daerah tidak tergantung dana dari pusat.
Berdasarkan uraian latar belakang penelitian yang telah diuraikan, maka permasalahan yang ditemui adalah sebagai berikut:

1. Berapa besar kebutuhan fiscal Kabupaten Lamongan?

2. Berapa besar kapasitas fiskal yang dimiliki Kabupaten Lamongan?

Pelaksanaan otonomi daerah dan desentralisasi fiskal yang didasarkan pada UU No. 22 tahun 1999 tentang pemerintahan daerah dan UU No. 25 tahun 1999 tentang perimbangan keuangan antara pemerintah pusat dan pemerintahan daerah memiliki makna yang berbeda dengan otonomi daerah berdasarkan UU No. 5 Tahun 1974.

Keuangan daerah yang termuat dalam penjelasan Undang Undang Nomor 32 Tahun 2004 tentang Pemerintahan Daerah, mengandung pengertian semua hak dan kewajiban daerah yang dapat dinilai dengan uang dan segala sesuatu berupa uang dan barang yang dapat dijadikan milik daerah yang berhubungan dengan pelaksanaan hak dan kewajiban tersebut. Dalam prinsip keuangan keuangan daerah terkandung unsur-unsur pokok. Unsur-unsur pokok dalam keuangan daerah adalah hak dan kewajiban daerah yang dapat dinilai, serta kekayaan yang berhubungan dengan hak dan kewajiban tersebut.

Hak daerah dalam rangka keuangan daerah adalah segala hak yang melekat pada daerah sesuai dengan peraturan perundangundangan yang digunakan dalam usaha pemerintah daerah mengisi kas daerah. Hak Daerah tersebut meliputi antara lain : 
1. Hak menarik pajak daerah (UU No. 18 Tahun 1997 jo UU No. 34 Tahun 2000)

2. Hak untuk menarik retribusi/iuran daerah (UU No. 18 Tahun 1997 jo UU No. 34 tahun 2000)

3. Hak mengadakan pinjaman (UU No. 33 tahun 2004 )

4. Hak untuk memperoleh dana perimbangan dari pusat (UU No. 33 tahun 2004)

Kewajiban daerah juga merupakan bagian pelaksanaan tugas-tugas Pemerintah pusat sesuai pembukaan UUD 1945 yaitu

1. melindungi segenap bangsa Indonesia dan seluruh tumpah darah Indonesia

2. memajukan kesejahteraan umum

3. mencerdaskan kehidupan bangsa

4. ikut serta melaksanakan ketertiban dunia yang berdasarkan perdamaian abadi dan keadilan sosial

Untuk

mendukung

penyelenggaraan otonomi daerah diperlukan kewenangan yang luas, nyata dan bertanggung jawab di daerah serta secara proporsional diwujudkan dengan pengaturan, pembagian dan pemanfaatan sumber daya nasional yang berkeadilan, serta perimbangan keuangan pemerintah pusat dan daerah. Sumber pembiayaan pemerintahan daerah dalam rangka perimbangan keuangan pemerintah pemerintahan daerah dalam rangka perimbangan keuangan pemerintah pusat dan daerah dilaksanakan atas dasar desentralisasi, dekonsentrasi dan tugas pembantuan.

APBD merupakan dasar pengelolaan keuangan daerah dalam satu tahun anggaran. APBD merupakan rencana pelaksanaan semua Pendapatan Daerah dan semua Belanja Daerah dalam rangka pelaksanaan Desentralisasi dalam tahun anggaran tertentu. Pemungutan semua penerimaan Daerah bertujuan untuk memenuhi target yang ditetapkan dalam APBD. Demikian pula semua pengeluaran daerah dan ikatan yang membebani daerah dalam rangka pelaksanaan desentralisasi dilakukan sesuai jumlah dan sasaran yang ditetapkan dalam APBD. Karena APBD merupakan dasar pengelolaan keuangan daerah.

Sejalan dengan ditetapkanya Peraturan Menteri Dalam Negari Nomor 13 Tahun 2006 yang antara lain mengatur pembagian kewenangan di bidang pemerintahan dan pelayanan kepada masyarakat yang berimplikasi pada kebutuhan pembiayaan daerah yang lebih besar, membawa konsekuensi pada perlunya pembagian sumber-sumber keuangan. Berkaitan dengan pembagian sumber-sumber keuangan. Sumber-sumber penerimaan daerah dalam rangka penerimaan desentralisasi adalah: 1) pendapatan asli daerah; 2) dana perimbangan; 3) lain-lain pendapatan asli daerah yang sah (Peraturan Menteri Dalam Negari Nomor 13 Tahun 2006).

Untuk mengetahui kinerja keuangan pemerintah dalam menjalankan otonomi daerah, salah satunya bisa di ukur melalui kinerja / kemampuan keuangan daerah. Berdasarkan Reksohadiprojo (2000) dalam bukunya "Ekonomi Publik" ada beberapa Analisis kinerja keuangan daerah diantaranya: 
1)desentralisasi fiskal, 2) kebutuhan fiskal, 3) kapasitas fiskal.

Adapun parameter yang digunakan yaitu:

\section{1.) Derajat desentralisasi fiskal}

Kemandirian daerah disini dimaksud adalah kemampuan pendapatan daerah seperti PAD,BHPBP dalam membiayai pengeluaran daerah seperti pengeluaran rutin dan pengeluaran pembangunan. Menurut Halim,(2001) parameter yang digunakan untuk mengukur tingkat kemandirian daerah adalah derajat kemandirian daerah, yaitu parameter untuk mengukur seberapa jauh penerimaan yang berasal dari daerah dalam memenuhi kebutuhan daerah Halim,(2001) dengan

menggunakan rasio sebagai berikut:

i. $\mathrm{PAD} / T P D \mathrm{X} 100$

ii. $B H P B P / T P D \times 100$

iii. $S u m / T P D \times 100$

Dimana :

$\mathrm{PAD}=$ Pendapatan asli daerah

BHPBP = Bagi hasil pajak dan bukan pajak

Sum $=$ Sumbangan Pemerintah pusat.

$\mathrm{TPD}=$ Total penerimaan daerah

$\mathrm{TPD}=\mathrm{PAD}+\mathrm{BHPBP}+\mathrm{SUM}$

Sum $=$ DAU + DAK + Pinjaman daerah + Lain-lain penerimaan yang sah

Semakin tinggi hasilnya, maka desentralisasi fiskal semakin tinggi pula Artinya Apabila jumlah PAD lebih besar dari bantuan dari pusat maka ketergantungan pemerintah daerah terhadap pemerintah pusat semakin kecil. Semakin tinggi hasilnya, maka desentralisasi fiskal semakin tinggi pula.

2.) Kebutuhan fiskal

Yaitu untuk mengukur kebutuhan pendanaan daerah untuk melaksanakan fungsi pelayanan dasar umum. Semakin tinggi indeks, maka kebutuhan fiskal suatu daerah semakin besar. Pengukuran dengan menghitung rata-rata kebutuhan fiskal standar se propinsi.dengan formula

$\mathrm{SKF}=$ Jumlah pengeluaran daerah / jumlah penduduk/ Jumlah kabupaten Kemudian menghitung Indeks Pelayanan Publik per kapita (IPP) masing masing pemerintah kota : dengan formula sebagai berikut:

IPP $=S K F / P P P$

Dimana

PPP $=$ pengeluaran Aktual perkapita untuk jasa publik ( jumlah pengeluaran pembangunan dan pengeluaran rutin)

IPP $=$ Indeks pelayanan publik perkapita

SKF = Standar Kebutuhan Fiskal

Semakin tinggi hasilnya, maka kebutuhan fiskal suatu daerah semakin besar

3.) Kapasitas fiskal (Fiskal capacity )

Untuk mengetahui kemampuan daerah dalam menghasilkan PAD dan dana bagi hasil yang diserahkan kepada pemerintah daerah guna membiayai pendanaan daerah..dengan penilaian, apabila kapasitas fiskal (PAD + dana Bagi hasil) lebih besar dari pengeluaran (kebutuhan fiskal) maka potensi untuk mendapatkan PAD didaerah tersebut cukup bagus tanpa ada bantuan dari pemerintah pusat. Indikator yang digunakan adalah sebagai berikut :

$\mathrm{FC}=\mathrm{PDRB} / K F s$

Dimana;

$\mathrm{FC}=$ kapasitas fiskal standar

KFs = Jumlah Penduduk /Jumlah kabupaten 
Apabila kapasitas fiskal (PAD + dana bagi hasil) lebih besar dari pengeluaran ( kebutuhan fiskal) maka potensi untuk mendapatkan PAD didaerah tersebut cukup bagus tanpa ada bantuan dari pemerintah pusat. Semakin tinggi hasilnya, maka kapasitas fiskal suatu daerah semakin tinggi.

Yuliati (2001) pada penelitiannya tentang kemampuan keuangan daerah dalam menghadapi otonomi daerah di Kabupaten Malang menyebutkan bahwa untuk mencapai kemandirian dangan mengandalkan PAD + bagi hasil, efeknya relatif lebih cepat daripada hanya mengandalkan PAD saja. Sementara penghitungan rasio PAD terhadap PDRB dengan menggunakan harga berlaku, menunjukkan hasil yang kurang baik. Penelitian ini menggunakan data runtut waktu (1995/19961999/2000).

Engleni (2001) yang meneliti tentang PAD di Kota Padang menyimpulkan perlunya rencana penerimaan PAD jangka menengah yang memenuhi unsur rasionalitas dan berorientasi ke depan. Skenario ini merupakan langkah penting sebagai respon semangat kemandirian pendanaan daerah. Disamping sebagai pedoman penentuan langkah dan tindakan oleh dinas/unit kerja pengelola penerimaan $\mathrm{PAD}$, juga sebagai tolok ukur keberhasilan dan kegagalan pelaksanaan kegiatan. Penelitian ini menggunakan pendekatan kausalitas yang dikaitkan dengan beberapa indikator pokok yaitu rata-rata pertumbuhan komponen PAD sebagai dasar untuk memprediksi rumusanny

Berdasarkan latar belakang penelitian dan kerangka pemikiran, dapat dirumuskan hipotesis sebagai berikut:

1. Kebutuhan fiscal Kabupaten Lamongan semakin meningkat

2. Kapasitas fiskal yang dimiliki Kabupaten Lamongan semakin besar

\section{Metode Penelitian}

Jenis penelitian ini termasuk dalam kategori penelitian dengan pendekatan analisis diskriptif komparatif-kuantitatif yaitu metode penelitian yang dilakukan untuk memecahkan masalah yang terjadi saat ini melalui analisa tentang perhubungan-perhubungan sebab akibat yakni yang memiliki faktorfaktor tertentu yang berhubungan dengan situasi atau fenomena yang diselidiki dan membandingkan satu faktor dengan faktor lainya (Surakhmad, 1990: 139). Unit analisis yang digunakan dalam penelitian ini adalah dinamika pendapatan asli daerah, penerimaan dan pengeluaran pemerintah daerah kabupaten Lamongan sejak dilaksanakanya otonomi daerah yaitu pada tahun 2009- 2013. Metode analisis data yang digunakan dalam penelitian ini adalah Kebutuhan fiskal dan Kapasitas fiskal (Fiskal capacity)

\section{HASIL ANALISIS}

Untuk menjadi kabupaten yang mandiri, kabupaten Lamongan harus melihat kebutuhan fiscal. 
Kebutuhan fiscal merupakan tolak ukur kebutuhan pendanaan daerah untuk melaksanakan fungsi pelayanan dasar umum. Semakin tinggi indeks, maka kebutuhan fiskal suatu daerah semakin besar. Pengukuran dengan menghitung ratarata kebutuhan fiskal standar se propinsi.

Tabel 1 Kebutuhan Fiskal Kabupaten Lamongan

\begin{tabular}{|r|r|}
\hline Tahun & Kebutuhan Fiskal \\
\hline 2009 & 15.59637 \\
\hline 2010 & 11.15532 \\
\hline 2011 & 12.64484 \\
\hline 2012 & 13.84868 \\
\hline 2013 & 13.74596 \\
\hline
\end{tabular}

Sumber: BPS Kab. Lamongan diolah

Kebutuhan fiscal kabupaten Lamongan secara umum fluktuaktif. Hal ini terlihat dari tren kebutuhan fiscal. Kebutuhan fiscal yang semakin besar mengindikasikan pengeluaran semakin meningkat. Peningkatan pengeluaran yang tidak sebanding dengan pendapatan yang diterima akan mengakibatkan ketimpangan. Hal ini membuat pemerintah kabupaten Lamongan melihat kemampuan daerahnya dalam mendapatkan pendapatan asli daerah. Hal ini biasa disebut dengan Kapasitas Fiscal.

Kapasitas fiscal dapat digunakan untuk mengetahui kemampuan daerah dalam menghasilkan PAD dan dana bagi hasil yang diserahkan kepada pemerintah daerah guna membiayai pendanaan daerah..dengan penilaian, apabila kapasitas fiskal (PAD + dana Bagi hasil) lebih besar dari pengeluaran (kebutuhan fiskal) maka potensi untuk mendapatkan PAD didaerah tersebut cukup bagus tanpa ada bantuan dari pemerintah pusat. Tabel 2 Kapasitas fiscal Kabupaten Lamongan

\begin{tabular}{|l|c|r|}
\hline Tahun & $\begin{array}{c}\text { PDRB per } \\
\text { Kapita }\end{array}$ & $\begin{array}{c}\text { Kapasitas } \\
\text { Fiskal }\end{array}$ \\
\hline 2009 & 3877.024 & 143.5935 \\
\hline 2010 & 4127.457 & 152.8688 \\
\hline 2011 & 5073.768 & 187.9173 \\
\hline 2012 & 5465.313 & 202.419 \\
\hline 2013 & 5908.127 & 218.8195 \\
\hline
\end{tabular}

Sumber: BPS Kab. Lamongan diolah

Berdasarkan tabel 2, Kabupaten Lamongan memiliki potensi untuk meningkatkan pendapatan asli daerahnya. Hal ini terlihat semakin besarnya kapasitas fiskal yang dimiliki Kabupaten Lamongan. Namun pada kenyataanya adalah pendapatan asli daerah yang mampu disumbangkan pada total pendapatan hanya $10 \%$. Sehingga dapat disimpulkan bahwa banyak potensi yang dimiliki oelh Kabupaten Lamongan yang belum tergarap dengan baik.

\section{PEMBAHASAN}

Dalam rangka penciptakan
good akuntabilitas publik yang kuat, maka laporan keuangan pemerintah daerah yang dihasilkan tersebut harus diupayakan untuk dapat secara sederhana dianalisis keterukurannya (akuntable) dan diakses dengan mudah (transparan) oleh umum (publik) dalam format yang lebih sederhana pada setiap variabel sesuai dengan sistem dan standar akuntansi 
keuangan pemerintah daerah yang baku.

\begin{tabular}{llr}
\multicolumn{2}{c}{ Kemampuan } & aparatur \\
pemerintah & daerah & dalam \\
melaksanakan & otonomi & daerah
\end{tabular}
khususnya di bidang pengelolaan keuangan daerah dapat dianalisis dari kinerja aparatur pemerintah daerah. Kinerja diartikan sebagai bentuk prestasi atau hasil dari perilaku pekerja tertentu yang merupakan fungsi dan komponen kemampuan (ability), dukungan (support), dan usaha (effort), untuk mengukur sebagian besar kinerja aparatur pemerintah daerah yang dapat diukur dengan kriteria efektivitas dan efisiensi.

Mardiasmo (1999: 11) mengemukakan bahwa salah satu aspek dari pemerintah daerah yang harus diatur secara hati-hati adalah masalah pengelolaan keuangan daerah dan anggaran daerah. Anggaran daerah atau Anggaran Pendapatan dan Belanja Daerah merupakan instrumen kebijakan, anggaran daerah menduduki posisi sentral dalam upaya pengembangan kapabilitas dan efektivitas pemerintah daerah. Anggaran Daerah seharusnya dipergunakan sebagai alat untuk menentukan besarnya pendapatan dan pengeluaran, alat bantu pengambilan keputusan dan perencanaan pembangunan, alat otoritas pengeluaran di masa yang akan datang. Ukuran standar untuk evaluasi ki-nerja serta alat koordinasi bagi semua aktivitas diberbagai unit kerja. Penentuan besarnya penerimaan/pendapatan dan pengeluaran/belanja daerah tidak terlepas dari peraturan perundangundangan yang berlaku. Anggaran mempunyai kegunaan pokok yaitu sebagai pedoman kerja, sebagai alat pengkoordinasian kerja serta sebagai alat pengawasan kerja. Dengan melihat kegunaan pokok dari anggaran tersebut maka pertumbuhan Anggaran Pendapatan dan Belanja Daerah dapat berfungsi sebagai: pertama fungsi perencanaan, dalam perencanaan APBD adalah penentuan tujuan yang akan dicapai sesuai dengan kebijaksanaan yang telah disepakati misalnya target penerimaan yang akan dicapai, jumlah investasi yang akan ditambah, rencana pengeluaran yang akan dibiayai. Kedua, fungsi koordinasi anggaran berfungsi sebagai alat mengkoordinasikan rencana dan tindakan berbagai unit atau segmen yang ada dalam organisasi, agar dapat bekerja secara selaras ke arah tercapainya tujuan yang diharapkan. Ketiga, fungsi komunikasi jika yang dikehendaki dapat berfungsi secara efisien maka saluran komunikasi terhadap berbagai unit dalam penyampaian informasi yang berhubungan dengan tujuan, strategi, kebijak-sanaan, pelaksanaan dan penyimpangan yang timbul dapat teratasi. Keempat, fungsi motivasi anggaran berfungsi pula sebagai alat untuk memotivasi para pelaksana dalam melaksanakan tugas-tugas yang diberikan untuk mencapai tujuan. Kelima, fungsi pengendalian dan evaluasi, anggaran dapat berfungsi sebagai alat-alat pengendalian yang pada dasarnya dapat membandingkan antara rencana dengan pelaksanaan sehingga dapat ditentukan penyimpangan yang timbul dan penyimpangan tersebut sebagai dasar evaluasi atau penilaian prestasi dan sekaligus merupakan 
umpan balik pada masa yang akan datang.

Pelaksanaan otonomi daerah merupakan proses yang memerlukan keterlibatan segenap unsur dan lapisan masyarakat, serta memberikan kekuasaan bagi pemerintah daerah dalam melakukan pengelolaan keuangan daerah sehingga peran pemerintah adalah sebagai katalisator dan fasilitator karena pihak pemerintahlah yang lebih mengetahui sasaran dan tujuan pembangun- an yang akan dicapai. Sebagai katalisator dan fasilitator tentunya membutuhkan berbagai sarana dan fasilitas pendukung dalam rangka terlaksananya pembangunan secara berkesinambungan. Anggaran belanja rutin merupakan salah satu alternatif yang dapat merangsang kesinambungan serta konsistensi pemba- ngunan di daerah secara keseluruhan me- nuju tercapainya sasaran yang telah dise- pakati bersama. Oleh sebab itu, kegiatan rutin yang akan dilaksanakan merupakan salah satu aspek yang menentukan keberhasilan pembangunan di daerah.

Menurut Abdul Halim (2004) desentralisasi fiskal memiliki berbagai keuntungan, yakni (1) meningkatnya demokrasi akar rumput (2) perlindungan atas kebebasan dan hak asasi manusia, (3) meningkatkan efisiensi melalui pendelegasian kewenangan, (4) meningkatkan kualitas pelayanan dan (5) meningkatkan pembangunan ekonomi dan sosial. Kemandirian Fiskal daerah merupakan salah satu aspek yang sangat penting dari otonomi daerah secara keseluruhan. Menurut Mardiasmo (1999) disebutkan bahwa manfaat adanya kemandirian fiskal adalah mendorong peningkatan partisipasi prakarsa dan kreativitas masyarakat dalam pembangunan serta akan mendorong pemerataan hasil-hasil pembangunan (keadilan) di seluruh daerah dengan memanfaatkan sumber daya serta potensi yang tersedia di daerah serta memperbaiki alokasi sumber daya produktif melalui pergeseran penghambilan keputusan publik ke tingkat pemerintahan yang lebih rendah yang memiliki informasi lebih lengkap.

Kemandirian fiskal daerah menggambarkan kemampuan pemerintah daerah dalam meningkatkan pendapatan asli daerah (PAD) seperti pajak daerah, retribusi dan lain-lain. Karena itu otonomi daerah dan pembangunan daerah bisa diwujudkan hanya apabila disertai kemandirian fiskal yang efektif. Ini berarti bahwa pemerintahan daerah secara finansial harus bersifat independen terhadap pemerintah pusat dengan jalan sebanyak mungkin menggali sumber - sumber PAD seperti pajak, retribusi dan sebagainya (Elia Radianto,1997).

Desentralisasi juga memiliki peran strategis dalam piranti kebijakan fiskal pemerintah, yang ditujukan untuk menyelaraskan dengan kebijakan ketahanan fiskal yang berkesinambungan dalam konteks kebijakan ekonomi makro dan memperkecil ketimpangan keuangan antara pemerintah pusat dan daerah serta mengoreksi ketimpangan antar daerah dalam kemampuan keuangan.

Salah satu aspek penting dari otonomi daerah secara keseluruhan adalah desentralisasi fiskal daerah (otonomi fiskal). Pengertian otonomi 
fiskal daerah menggambarkan kemampuan pemerintah daerah dalam meningkatkan pendapatan asli daerah seperti pajak, retribusi dan lain-lain. Karena itu pemerintah daerah secara financial harus bersifat independen terhadap pemerintah pusat dengan jalan sebanyak mungkin menggali sumber-sumber PAD (Radianto, 1997, 42).

Kemampuan daerah dalam membiayai pembangunan masih sering mengalami kendala berupa rendahnya kemampaun daerah dalam meningkatkan PADnya. Indikator rendahnya kemampuan daerah in dapat dilihat dari Indeks Kemampuan Rutin (IKR) daerah, yang diperoleh dari besarnya perubahan PAD terhadap pengeluaran rutin daerah dalam persentase tahun yang sama. Realitas hubungan fiskal antara pemerintah pusat dengan pemerintah daerah ditandai dengan tingginya kontrol pusat terhadap pembangunan daerah. Hal ini terlihat jelas dari rendahnya PAD terhadap total pendapatan daerah dibandingkan dengan total subsidi yang didrop dari pusat. Indlikator desentralisasi fiskal adalah rasio antara PAD dengan total pendapatan daerah.

\section{KESIMPULAN DAN SARAN}

Sesuai dengan tujuan analisis, studi ini ingin mengetahui seberapa besar tingkat kemandirian fiskal kabupaten Lamongan. Berdasarkan analisis pada Bab 6, maka dapat diambil kesimpulan antara lain sebagai berikut :

1. Kebutuhan fiskal kabupaten Lamongan sangat tinggi. Tingginya kebutuhan fiskal Kabupaten Lamongan tidak terlepas dari pengeluaran pembangunan yang sangat tinggi disamping pengeluaran rutin yang terus meningkat.

2. Kapasitas fiskal Kabupaten Lamongan sangat baik. Kemampuan dalam memenuhi atau meningkatkan pendapatan asli daerah kurang digali secara penuh oleh Kabupaten Lamongan. Hal ini terlihat dari kapasitas fiskal yang semakin meningkat namun sumbangan pendapatan asli daerah terhadap total pendapatan sangat rendah.

Berangkat dari hasil kesimpulan diatas, maka timbul pemikiran kedepan yang tertuang dalam implikasi kebijakan sebagai berikut :

1. Untuk meningkatkan pendapatan asli daerah Kabupaten Lamongan perlu menggali potensi ekonomi lokal seperti pengembangan pariwisata dan pengembangan pusat agrobisnis.

2. Pos anggaran harus efektif dan efisien sehingga dapat menyentuh sasaran kebijakan guna peningkatan pendapatan asli daerah

3. Meningkatkan investasi dengan menciptakan iklim investasi yang kondusif di Kabupaten Lamongan serta menjaga persaingan usaha antar badan usaha guna terciptanya laju pertumbuhan 
ekonomi yang tinggi dan dinamis.

4. Pemerintah daerah agar berusaha untuk mendapatkan bagi hasil dari pusat terkait sumberdaya daerah yang peenerimaannya disetor seluruhnya ke pusat, sebagai contoh bagi hasil cukai yang semuanya merupakan penerimaan pemerintah pusat.

\section{DAFTAR PUSTAKA}

Arsyad, Lincolin, 1999, Ekonomi Pembangunan. Yogyakarta: Badan Penerbit Fakultas Ekonomi (BPFE). Yogyakarta

BPS Lamongan. 2008.

Depdagri. 1974. Undang-undang Nomor 5 tentang Pemerintah Daerah. Jakarta: Percetakan RI.

Depdagri. 1993. Tap MPR RI No.II/MPR/1988 tentang GBHN. Jakarta: Percetakan RI.

Depdagri. 1999. Undang-undang Nomor 22 tentang Pemerintah Daerah. Jakarta: Percetakan RI.

Depdagri. 1999. Undang-undang Nomor 25 tentang Perimbangan Keuangan antar PemerintahPusat dan Pemerintah Daerah. Jakarta: Percetakan RI.

Depdagri. 2004. Undang-undang Nomor 32 tentang Pemerintah Daerah. Jakarta: Percetakan RI.
Depdagri. 2006. Peraturan Menteri Dalam Negeri Nomor 13. Jakarta: Percetakan RI.

Dumairi. 1987. Kausalitas Antara Uang Beredar dan Inflasi di Indonesia. Jurnal Ekonomi dan Bisnis Indonesia. No. 2. ha13-14.

Gujarati, D.N. 1995. Basic Econometrics.3 Edition. MacGraw-Hill International Edition.

Irawan, dan Suparmoko. 1987. Ekonomi Pembangunan. Yogya : Liberty.

Jhingan , ML. 2000. Ekonomi Pembangunan dan Perencanaan. Jakarta: PT. Raja Grafindo Persada.

Kabupaten Lamongan. 2008. Profil dan Potensi Kabuparen Lamongan.

Kaho, J.R, 2001. Prospek Otonomi Daerah di Negara Republik Indonesia : Identifikasi beberapa faktor yang mempengaruhi penyelenggaraannya. Jakarta : Raja Grafindo Persada

Nuryasman. 1996. Pengembangan Konsep Pusat Pertumbuhan Terhadap Wilayah Kepulauan Indonesia. Jakarta. Media Ekonomi Trisakti

Simanjuntak, Payaman, 1998, Pengantar Ekonomi Sumberdaya Manusia, Edisi 2001, Lembaga Penerbit Fakultas Ekonomi UI. Jakarta. Sumodiningrat, Gunawan. 1999. Pemberdayaan Rakyat. Jakarta : Gramedia Pustaka Utama. 
Sukirno, Sadono. 1948. Pe.:gantar

Teori lviakroekonomi. Jakarta:

PT. Raja Grafindo Fersada.

Wijayanti, Kencana Sari. 1996. Tingkat Kemandirian

Pendapatan Asli Daerah

Kabupaten Daerah Tangkat II

Situbondo !983-1992. Tesis.

Tidak Dipublikasikan.

Lamongan: FE-UNEJ.

Adiputra, Andre Kussuma. 2001.

Kausalitas Antara

Pertumbuhan Ekonomi dan

Deficit Anggaran Pemerintah di Indonesia; 1969-1998. PS.

Studi Pembangunan Thesis.

Universitas Gadjah Mada.

Tidak dipublikasikan. Aliman.

1998. Kausalitas Antara

Jumlah Uang Beredar dan

Tingkat Pendapatan Nasional,

Studi Kasus Indonesia dan

Thailand. Skripsi S1. Fakultas

Ekonomi. Universitas Gadjah

M2da. Tidak dipublikasikan.

Arsyad. Lincolin. 1999. Pengantar Perencanaan

Dan

Pembangunan

Ekonomi

Daarah. Yogyakarts: BPFE.

Ariet; Sritua. 199S. A,:atodologi Penelitian F.konomi. Jakarta: UI-Press.

Aziz, Iwan Jaya. i994. Ilmu Ekonomi Regional don beberapa Aplikasirrya di Indonesia. Jakarta_LP FEUt.

Blakely, Edward J. 1988. Planning Local Economic Development Theory and Practice. Newbury, California: Sage Publication, Inc.

Depdagri. 1993. Tap MPR RI No.II/MPR/1988 tentang GBHN. Jakarta: Percetakan RI.
Dunn, William N. 2000. Pengaruh Analisis Kebijakan Publik. Yogyakarta: Gadjah Mada Press.

Djenen, dkk. 1995. Kesadaran Budaya Tentang Tata Ruang Di Daerah Kalimantan Selantan. Jakarta: Departemen Pendidikan dan Kebudayaan.

Dumairi. 1987. Kausalitas Antara Uang Beredar dan Inflasi di Indonesia. Jurnal Ekonomi dan Bisnis Indonesia. No. 2. ha13-14..

Gujarati, D.N. 1995. Basic Econometrics..3 Edition. MacGraw-Hill International edition.

Islamy, Irfan M. 2000. Prinsip Prinsip Perumusan Kebijaksanaan Negara. Jakarta: PT. Bumu Aksara.

Jamal dan Djauhari. 1998. Kebijaksanaan Pengendalian Alih Fungsi Lahan Sawah. Jakarta: Perhepi.

Jhingan , ML. 2000. Ekonomi Pembangunan dan Perencanaan. Jakarta: PT. Raja Grafindo Persada.

Kuncoro, Mudrajad 2003. Metode Riset Untuk Bisnis dan Ekonomi. Jakarta: Erlangga

Kay, Ulli Rahmi. 2003. Uji Kausalitas Hubungan Antara Harga Beras-'Dan Tingkat Inflsi Di Sumatera Selatan (Penerapan Uji Kausatitas Granger). Jurnal EP UNSRI. Palembang.

Machmud, Sofyan. 2003. Analisis Investasi dan Pertumbuhan Ekonomi Propinsi Sumatera Selatan. Thesis. PPS 
Universitas Sriwijaya

Palembang. McEachem,

Maknun, Mappaujung. 1995. Kausalitas Antara

Pertumbuhan Ekonomi dan Inflasi. PS. Studi

Pembangunan :Thesis.

Universitas Gadjah Mada.

Tidak dipublikasikan.

Marwa, Taufiq. 2001. Respon Pelaku Pasar Komoditi Beras

Terhadap Perubahan Variabel Harga dan Bukan Harga di Propinsi Sumatera Selatan. Disertasi. PPS UTv'PAD Bandung

Ngurah Agung, I Gusti. Statistika : Analisis Nubungan Kausal Berdasarkcrn Data Kategotik. Jakarta: PT. Raja Grafindo. Nusantara.

Ramanathan, Ranu. 1992. Deficit Finance and Economic Growth. Thesis Master, Departement of Accounting and Finance. University of Birmingham. Unpublished.

Reksohadiprodjo dan Karseno. 1993. Ekonomi Perkotaan. Yogyakarta: BPFE.

Reksohadiprodjo dan Pradono. 1998. Ekonomi Sumber Daya Alam dan Energi. Yogyakarta: BPFE.

Sading, Yunus. 1999. Pengaruh Investasi Pemerintah Terhadap Pertumbuhan dan Perubahan Struktur Perekonomian Daerah Tingkat I Sulawesi Tengah. Thesis. Ekonomi dan Studi Pembangunan.

IJNPAD Bandung.

Siregar, Masdjidin. 1999. Kausalitas Antara Ekspor dan PDB di
Indonesia, 197i1997. Jurnal Ekonomi dan Keuangan Indonesia. VoLXLVII No. 3. Suharto. Apakah terdapat Hubungan Kausalitas Antara Pertumbuhan Ekonomi dengan Investasi Asing Langsung? Jurnal Ekoraomi Univ. Krisna Dwipayana.

Spillane dan Wan. 1993. Materi Pokok Ekonomi Regional. Jakarta: Universitas Terbuka.

Sugandhy. 1994. Operasional Penataan Ruang dan Trilogi Pembangunan. Jakarta: LP3ES.

Sujarto. 1986. Pemekaran Kota atau Dekonsentrasi Planalogis. Tinjauan Mengenai Hubungan Pemukiman Desa - Kota. Jakarta: LP3ES.

Sukirno, Sadono. 1948. Pe.:gantar Teori lviakroekonomi. Jakarta: PT. Raja Grafindo Fersada.

Suntowo, Bambang. 2006. Analisis Penggunaan Terbaik dan Tertinggi dan TOWS terhadap Tanah Kosong (studi kasus di jalan raya Jombang-Mojokerto Kecamatan Mojoagung Kabupaten Jombang). Tesis. Tidak Dipublikasikan. Yogyakarta: UGM.

Supranto. 1995. Ekonometrik. Yogyakarta: BPFE.

Suryana dan Pasandaran. 1993. Peranan Pertanian dalam Meningkatkan Pendapatan Masyarakat. Jakarta: LP3ES.

Thomas, R.L. 1997. Modern Econometric: An Introduction. London: AddisonFJesley Longman.

Wadu,:, Muhammad. 2003. FaktorFaktor Yang Mempengaruhi 
Pertumbuhar. Ekonomi

Kabunaten h:usi Banyuasin.

Thesis. PPS Universitas

Sriwijaya Palembang.

Wagito. 1992. Studi Evaluasi Perubahan Penggunaan Lahan di Setiap Satuan Wilayah Pembangunan (SWP). Laporan Penelitian. Lamongan: Lemlit UNEJ.

Wardhany, Rosalina. 2003. Analisis

Konversi Lahan dari Sektor Pertanian ke Non Pertanian di Kabupaten Lamongan. Skripsi. Tidak Dipublikasikan. Lamongan: FE-UNEJ.

Yunus, Hadi S. 2000. Struktur Tata Ruang Kota. Yogyakarta:

Pustaka Pelajar. 